
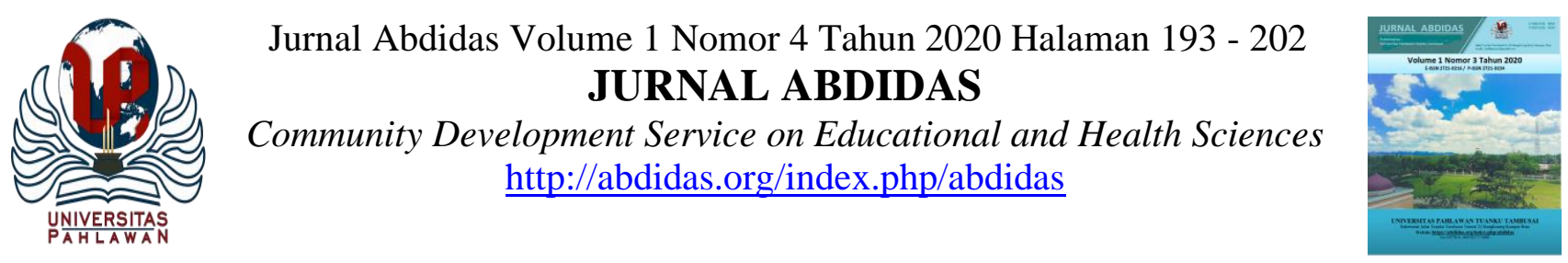

\title{
Penguatan Pembelajaran Matematika Siap Menghadapi Ujian Dengan Model Pembelajaran Assurance-Relevance-Interest-Assessment-Satisfaction Di Yayasan Nurul Falah Talok Tangerang
}

\author{
Jaka Wijaya Kusuma1, Rani Septiani Sukandar², Hamidah ${ }^{3}$ \\ Jurusan Pendidikan Matematika, Fakultas Keguruan dan Ilmu Pendidikan, Universitas Bina Bangsa, Serang ${ }^{123}$

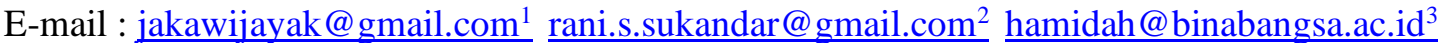

\begin{abstract}
Abstrak
Menghadapi ujian yang semakin dekat memunculkan permasalah bagi siswa. Adapun tujuan kegiatan ini: 1) meningkatkan kepercayaan diri siswa dalam menghadapi ujian; 2) meningkatkan kemampuan siswa dengan model pembelajaran Assurance-Relevance-Interest-Assessment-Satisfaction. Metode yang digunakan adalah metode survei dengan menyebarkan kuesioner sebagai feedback dari mitra. Hasil kuesioner diperoleh 68\% siswa sangat setuju bahwa instruktur memberi kesempatan kepada siswa untuk bertanya, 52\% siswa sangat setuju bahwa instruktur memberikan soal-soal dan pembahasan dengan jelas, 55\% siswa sangat setuju bahwa instruktur membantu siswa memahami materi dan soal dengan baik, 38\% siswa sangat setuju bahwa kegiatan membuat siswa merasa lebih percaya diri menghadapi ujian, 52\% siswa sangat setuju bahwa isi materi jelas dan mudah dipahami, dan $73 \%$ siswa sangat setuju bahwa proses pembelajaran sangat menyenangkan. Kesimpulan dari kegiatan menunjukan bahwa proses pembelajaran dengan model Assurance-Relevance-Interest-Assessment-Satisfaction berjalan dengan baik dan terbukti meningkatkan rasa percaya diri siswa dalam menghadapi ujian sekaligus meningkatkan kemampuan matematika siswa dengan cara menciptakan suasana kelas yang aktif dan menyenangkan sehingga perlu diterapkan dalam pembelajaran di kelas.
\end{abstract}

Kata kunci: Assurance-Relevance-Interest-Assessment-Satisfaction (ARIAS), matematika, percaya diri

\begin{abstract}
Examination raises the problem for students. The purpose of this activity is: 1) Increase the confidence of students in the face of the exam; 2) Enhance students ' ability with the Assurance-Relevance-Interest-AssessmentSatisfaction learning model. The method used is a survey method by spreading questionnaires as feedback from partners. The results of the questionnaire obtained $68 \%$ of students strongly agree that the instructor allowed students to ask, 52\% of students strongly agree that the instructor gave questions and discussions clearly, 55\% of students strongly agree that the instructor helps students understand the material and questions well, $38 \%$ of students strongly agree that the activity makes students feel more confident facing the exam, 52\% of students strongly agree, and $73 \%$ of students strongly agree that the learning process is very enjoyable. The conclusion of the activity showed that the learning process with the Assurance-Relevance-Interest-Assessment-Satisfaction model went well and proved to increase students ' self-confidence in the face of the exam while improving students ' mathematical skills by creating an active and enjoyable class atmosphere that needs to be applied in classroom learning.
\end{abstract}

Keywords: Assurance-Relevance-Interest-Assessment-Satisfaction (ARIAS), mathematics, confidence

Copyright (c) 2020 Jaka Wijaya Kusuma, Rani Septiani Sukandar, Hamidah

$\triangle$ Corresponding author :

Address : Universitas Bina Bangsa

Email : jakawijayak@gmail.com

ISSN 2721 - 9224 (Media Cetak)

DOI: https://doi.org/10.31004/abdidas.v1i4.43

ISSN 2721 - 9216 (Media Online) 

Assurance-Relevance-Interest-Assessment-Satisfaction Di Yayasan Nurul Falah Talok Tangerang Jaka Wijaya Kusuma, Rani Septiani Sukandar, Hamidah

DOI: https://doi.org/10.31004/abdidas.v1i4.43

\section{PENDAHULUAN}

Berdasarkan hasil Survei Programme for International Student Assessment (PISA) yang dilakukan kepada peserta didik dengan usia 15 tahun pada 2015 seperti yang disampaikan oleh Dirjen Pembelajaran dan Kemahasiwaan Kemristek dikti, Intan Ahmad, diperoleh bahwa kemampuan matematika peserta didik Indonesia berada pada peringkat ke-63 dari 70 negara, kalah jauh dibanding Vietnam yang berada di peringkat ke-12 dan Singapura di peringkat pertama. Presiden ke-2 Himpunan Matematika Indonesia Indonesian Mathematical Society (IndoMS), Bana Kartasasmita, menengarai bahwa keterpurukan tersebut disebabkan oleh banyak faktor, diantaranya adalah kurikulum, pengajar, sarana, termasuk dukungan orang tua peserta didik. Lebih lanjut, Bana Kartasasmita mengatakan bahwa pendekatan pembelajaran yang bertumpu pada berhitung dan menghafal rumus merupakan penyebab utama keterpurukan ini. Seharusnya pembelajaran matematika bertumpu pada berpikir bagaimana bisa membuat rumus dan bagaimana mengaplikasikan matematika dalam kehidupan sehari-hari (Mohammad Imam Utoyo, Siti Erum Megawati, 2019).

Pendidikan merupakan sesuatu yang sangat penting bagi kehidupan manusia, maka perlu pelaksanaan yang sangat baik dalam pelaksanaan pendidikan agar hasil yang diperoleh sesuai harapan. Peran guru menjadi sangat penting dalam pelaksanaan pendidikan khususnya dalam mencerdaskan siswanya. Siswa adalah manusia yang masih dalam fase pertumbuhan, sehingga tiap perbuatan dan tingkah lakunya merupakan suatu bentuk timbal balik dari lawannya. Dengan kata lain, dalam proses pembelajaran siswa akan memperhatikan dan semangat mengikuti pelajaran jika guru memberikan feedback atau respon yang baik akan setiap keterampilan siswa.

Sikap guru yang biasa saja atau bahkan memberi respon negatif terhadap sikap siswa, akan membuat siswa patah semangat dan enggan untuk melanjutkan keterampilan atau keingintahuannya. Sering sekali ditemui guru jarang atau enggan memuji perbuatan siswa yang sekedar mau angkat tangan untuk maju ke depan, apalagi jika siswa tersebut salah tidak jarang guru memberikan respon negatif. Guru adalah penunjang untuk keberhasilan siswa dalam proses pembelajaran, sehingga guru perlu memiliki keterampilan dasar mengajar yaitu keterampilan memberikan penguatan (reinforcement). Guru juga harus memiliki rasa empati dan memahami kebutuhan moril siswa. Jadi, dengan adanya penguatan misalnya memberikan balasan positif kepada siswa sehingga siswa akan berbesar hati dan meningkatkan partisipasinya dalam setiap proses pembelajaran. Diharapkan dengan tumbuhnya motivasi siswa dalam proses pembelajaran dan meningkatnya perhatian siswa, maka prestasi belajarnya pun diharapkan dapat meningkat. Maka jika hatinya senang, ia akan lebih bersemangat dalam belajar (Maslichah Kumalaningrum, 2013).

Menghadapi ujian yang semakin dekat memunculkan permasalah tersendiri pada siswa, baik berupa pengetahuan yang perlu penguatan materi maupun perlunya motivasi dari luar ataupun dalam diri siswa itu sendiri agar yakin dan percaya akan kemampuan diri sendiri. Adapun masalah 

Assurance-Relevance-Interest-Assessment-Satisfaction Di Yayasan Nurul Falah Talok Tangerang Jaka Wijaya Kusuma, Rani Septiani Sukandar, Hamidah

DOI: https://doi.org/10.31004/abdidas.v1i4.43

yang ada di Yayasan Nurul Falah Talok berdasarkan wawancara awal dengan guru bidang studi matematika yaitu: 1) siswa kurang percaya diri dalam menghadapi ujian; 2) kesulitan siswa pada materi aljabar dan geometri terutama dalam perhitungan aljabar dan mengkonstruksi atau menganalitik bangun geometri. Hasil ulangan harian sebelumnya juga menunjukan bahwa nilai pada materi aljabar maupun geometri lebih rendah dibandingkan dengan materi yang lain. Disamping itu, model pembelajaran yang selama ini diterapkan guru adalah ceramah, tanya jawab, dan penugasan.

Hasil observasi pada saat pembelajaran menunjukkan bahwa guru cendrung hanya memberi bekal kemampuan berupa hapalan dan kurang menekankan pada pemahaman siswa. Kesulitan siswa dalam memahami materi dapat disebabkan oleh berbagai faktor diantaranya, model pembelajaran yang digunakan guru dan cara mengajar guru. Hal ini jelas bahwa guru menjadi salah satu sumber penting terhadap kemampuan siswa dalam memahami atau mempersulit materi yang sedang dijelaskan.

Solusi yang akan diberikan terhadap permasalah mitra PKM adalah memberikan pembelajaran dengan menerapkan model pembelajaran yang dapat menciptakan suasana kelas menjadi aktif dan menyenangkan, diharapkan bisa menjadi penguatan pembelajaran matematika agar siap menghadapi ujian sekaligus meningkatkan rasa percaya diri siswa. Model pembelajaran yang dianggap mampu meningkatkan pencapaian tersebut adalah pembelajaran kooperatif (Nur \& Dkk, 2013) dan dengan model pembelajaran Assurance-RelevanceInterest-Assessment-Satisfaction (ARIAS). Model pembelajaran ARIAS oleh Keller dan Kopp yaitu terdiri dari lima komponen assurance, relevance, interest, assessment, dan satisfaction. Adapun kegiatan pada pembelajarannya berdasarkan penelitian (Hamidah \& Kusuma, 2019) setelah dikemas mampu mendorong siswa untuk aktif saat proses pembelajaran berlangsung dengan menanamkan rasa percaya pada diri sendiri, menciptakan kegiatan yang relevan dengan materi yang akan disampaikan, membangkitkan minat dan perhatian siswa dengan menampilkan sesuatu yang berbeda, kemudian melakukan assessment dan memunculkan perasaan bangga pada diri sendiri dan puas terhadap hasil kerjanya.

Berdasarkan hal di atas, penulis merasa perlu melakukan upaya peningkatan pemahaman, keterampilan dan kepercayaan diri siswa dalam menghadapi ujian di Yayasan Nurul Falah Talok. Adapun tujuan kegiatan pengabdian ini adalah: 1) meningkatkan rasa percaya diri siswa dalam menghadapi ujian; 2) meningkatkan kemampuan dengan cara menciptakan suasana kelas yang aktif dan menyenangkan melalui model pembelajaran Assurance Relevance Interest Assessment Satisfaction (ARIAS).

\section{METODE}

Metode pengumpulan datanya yaitu observasi keadaan kelas selama proses pembelajaran, wawancara langsung kepada siswa, dokumentasi berupa foto kegiatan, dan kuesioner yang diberikan setelah pembelajaran. Subjek penelitian ini adalah siswa MA dan MTs Nurul 

Assurance-Relevance-Interest-Assessment-Satisfaction Di Yayasan Nurul Falah Talok Tangerang Jaka Wijaya Kusuma, Rani Septiani Sukandar, Hamidah

DOI: https://doi.org/10.31004/abdidas.v1i4.43

Falah Talok yang berjumlah 3 kelas. Langkahlangkah dari awal persiapan kegiatan sampai pembuatan laporan dilakukan pada bulan Maret tahun 2019. Berikut disajikan pada gambar 1.

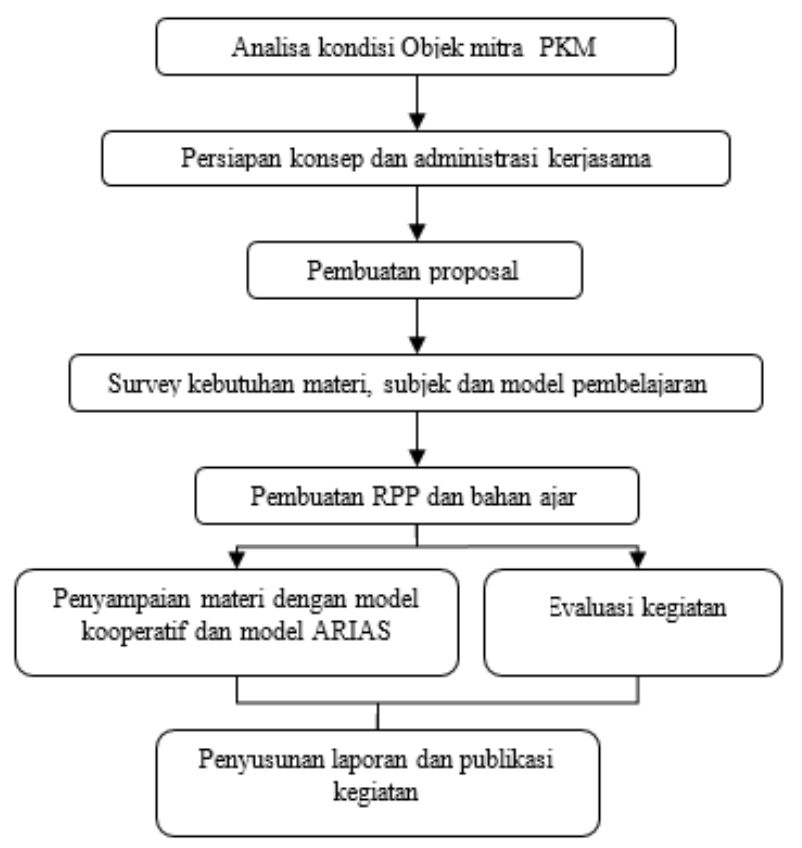

Gambar 1. Tahapan Kegiatan PKM

Uraian kegiatan program pengabdian kepada masyarakat (PKM) diantaranya adalah sebagai berikut:

1. Analisa kondisi obyek mitra pengabdian kepada masyarakat yaitu survey atau wawancara dilakukan kepada mitra pengabdian kepada masyarakat sekaligus menjadi objek atau target pelaksanaan PKM yaitu siswa MA dan MTs Nurul Falah Talok yang berjumlah 3 kelas. Analisa dilakukan untuk mengetahui permasalahan yang sedang dialami siswa dan solusi apa yang diperlukan untuk mengatasinya.
2. Persiapan konsep dan administrasi kerjasama yaitu koordinasi dan persiapan kegiatan PKM kepada antar tim terkait materi yang dianggap mengalami banyak kesulitan serta model pembelajaran yang akan diterapkan untuk mengatasi kesulitan tersebut serta persiapan apa yang diperlukan. Kemudian administrasi antara mitra dan Universitas Bina Bangsa.

3. Pembuatan proposal yaitu membuat proposal kegiatan pengabdian kepada masyarakat sebagai salah satu administrasi dalam program kegiatan di Universitas Bina Bangsa.

4. Survey kebutuhan materi, subjek dan model pembelajaran yaitu melakukan survey di sekolah dan melakukan diskusi dengan mitra terkait prosedur kegiatan yang akan diterapkan selama kegiatan. Subjek kegiatan adalah siswa MA dan MTs Nurul Falah Talok yang berjumlah 3 kelas.

5. Pembuatan RPP dan bahan ajar yaitu membuat rancangan proses pembelajaran dengan model kooperatif dan model ARIAS sesuai tahapan dari model tersebut serta menyiapkan bahan ajar/soal dab pembahasannya terkait materi yang akan disampaikan nanti yaitu aljabar dan geometri.

6. Penyampaian materi dengan model kooperatif dan model ARIAS yaitu pada tahapan ini dilakukan dengan dua cara diantaranya: a) pendekatan kepada siswa dengan cara menyampaikan maksud kegiatan, tujuannya untuk menarik perhatian siswa selama kegiatan berlangsung; b) mengelompokan siswa secara acak sesuai dengan model yang akan diterapkan; c) menyampaikan konsep 

Assurance-Relevance-Interest-Assessment-Satisfaction Di Yayasan Nurul Falah Talok Tangerang Jaka Wijaya Kusuma, Rani Septiani Sukandar, Hamidah

DOI: https://doi.org/10.31004/abdidas.v1i4.43

dasar dari aljabar dan geometri dengan cara yang menyenangkan sesuai tahapan dari model ARIAS, diharapkan memberi pemahaman konsep yang berkesan dan mengubah pandangan siswa terhadap matematika menjadi pembelajaran yang mudah dan menyenangkan sehingga memunculkan rasa percaya diri siswa dalam menghadapi ujian nanti; d) membahas soal-soal matematika yang sering muncul selama ujian serta memberikan kiat-kiat siap menghadapi ujian, hal ini menjadi senjata yang dirasa ampuh untuk meningkatkan rasa percaya diri siswa dalam menghadapi ujian; e) memberikan reward kepada siswa yang berani maju ke depan untuk merespon atau menjawab pertanyaan yang diberikan, sehingga menjaga ketertarikan siswa untuk terus terlibat selama proses kegiatan/pembelajaran berlangsung; f) diakhir kegiatan diselingi dengan game untuk memberikan kesan santai selama proses kegiatan.

7. Evaluasi kegiatan yaitu memberikan kuesioner kepada siswa untuk menerima feedback dari kegiatan yang telah dilakukan sehingga pelaksanaan PKM selanjutnya dapat lebih baik lagi.

8. Penyusunan laporan dan publikasi kegiatan.

\section{HASIL DAN PEMBAHASAN}

Pada kegiatan PKM ini yang menjadi subjek penelitian ini adalah siswa MA dan MTs Nurul Falah Talok yang berjumlah 3 kelas. Kelas pertama berjumlah 22, kelas kedua berjumlah 17 , dan kelas ketiga berjumlah 25. Tiap kelas terdiri dari dua instruktur/dosen matematika yang menyampaikan materi sesuai bahan ajar yang sudah disiapkan dan dengan tahapan sesuai RPP yang dibuat bersama-sama yaitu dengan model kooperatif dan model ARIAS. Seluruh siswa mengikuti kegiatan dengan respon yang positif, siswa tampak sangat bersemangat dan interaktif menanggapi apa yang disampaikan instruktur. Hal ini dapat dilihat dari hasil dokumentasi berikut:

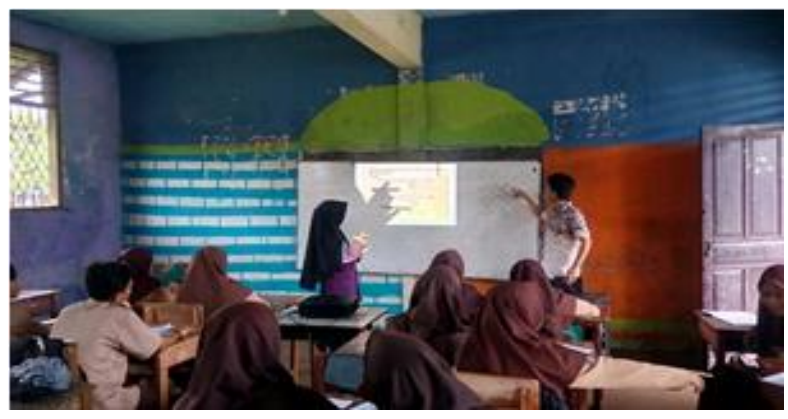

Gambar 2. Instruktur Memberikan Materi

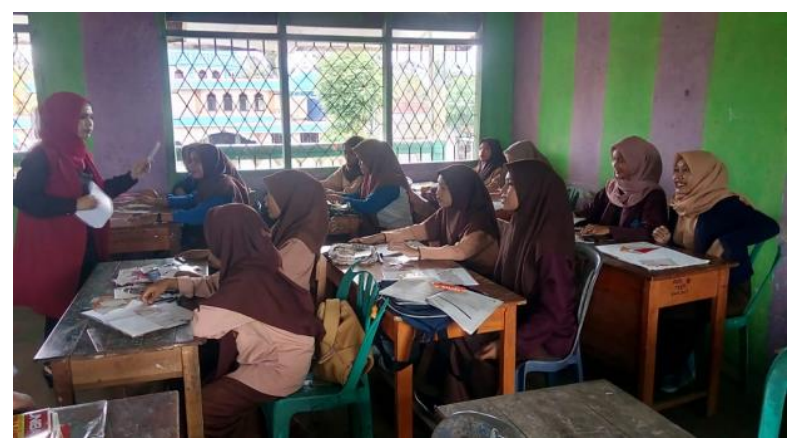

Gambar 3. Instruktur Membahas Soal-soal Matematika Dan Kiat Menghadapi Ujian

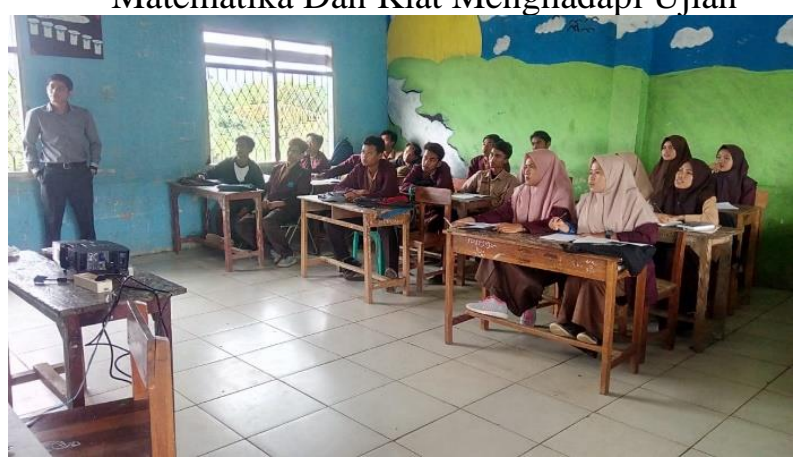



Assurance-Relevance-Interest-Assessment-Satisfaction Di Yayasan Nurul Falah Talok Tangerang Jaka Wijaya Kusuma, Rani Septiani Sukandar, Hamidah

DOI: https://doi.org/10.31004/abdidas.v1i4.43

Gambar 4. Siswa Menyimak Selama Proses Kegiatan

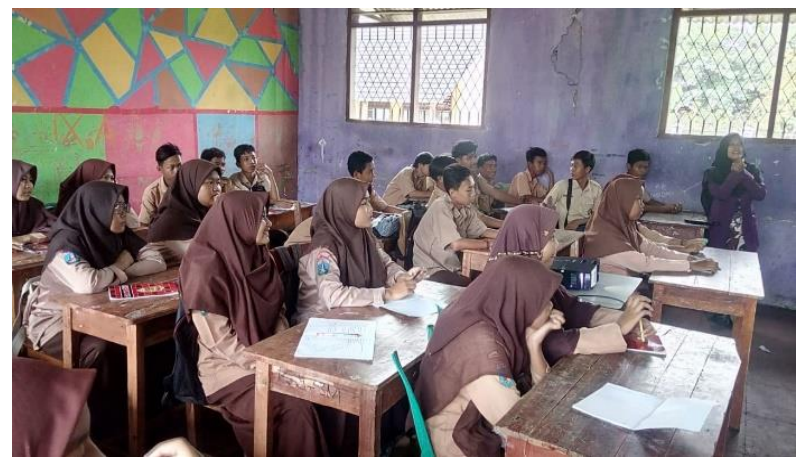

Gambar 5. Siswa Diberikan Game

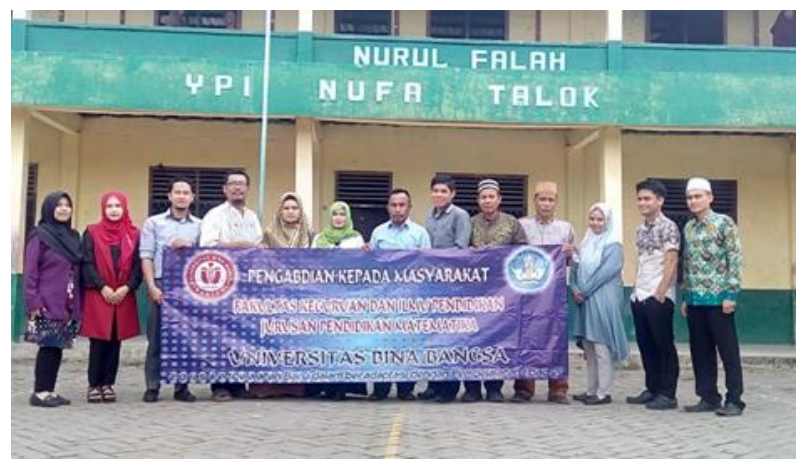

Gambar 6. Instruktur dan Guru Sekolah

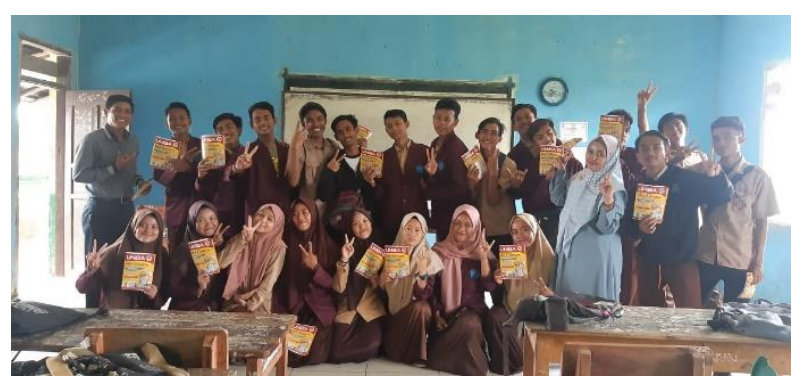

Gambar 7. Antusias Instruktur Dan Peserta

Adapun hasil evaluasi berupa angket kuesioner yang diberikan kepada siswa setelah kegiatan berakhir yaitu:

a. Instruktur memberi kesempatan kepada siswa untuk bertanya

Hasil angket kuesioner yang diberikan kepada siswa dengan pernyataan bahwa "Instruktur memberi kesempatan kepada siswa untuk bertanya" diketahui bahwa $68 \%$ siswa menyatakan sangat setuju, perhatikan gambar berikut:

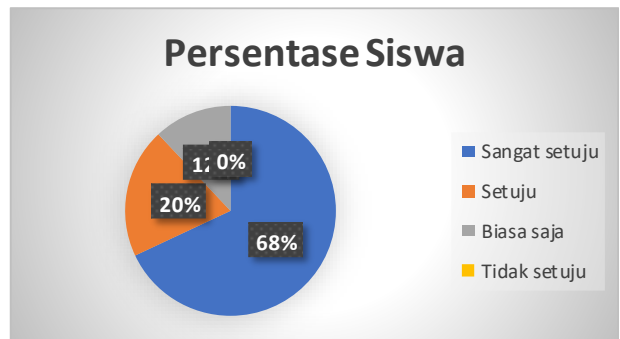

Gambar 8. Hasil Kuesioner Instruktur Memberi Kesempatan Kepada Siswa Untuk Bertanya

Gambar 8 menunjukan bahwa sebagian besar siswa sangat setuju bahwa pada saat kegiatan instruktur memberikan kesempatan kepada siswa untuk bertanya. Menurut (Rohman \& Susilo, 2019) sebagai fasilitator guru berperan penting dalam memberikan ruang kepada siswa untuk bertanya sehingga siswa bisa lebih aktif dan kreatif selama kegiatan pembelajaran.

b. Instruktur memberikan soal-soal dan pembahasan dengan jelas

Hasil angket kuesioner yang diberikan kepada siswa dengan pernyataan bahwa "Instruktur memberikan soal-soal dan pembahasan dengan jelas" diketahui bahwa 52\% siswa menyatakan sangat setuju, gambar berikut:

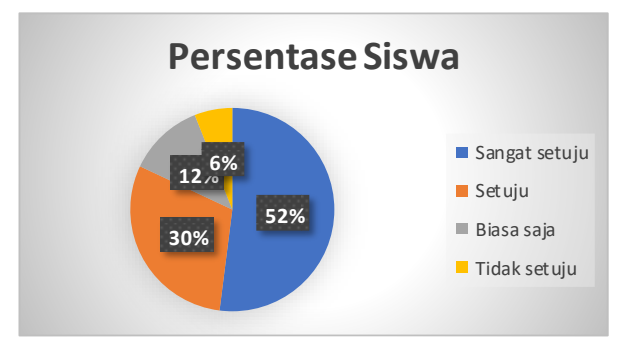



Assurance-Relevance-Interest-Assessment-Satisfaction Di Yayasan Nurul Falah Talok Tangerang Jaka Wijaya Kusuma, Rani Septiani Sukandar, Hamidah

DOI: https://doi.org/10.31004/abdidas.v1i4.43

Gambar 9. Hasil Kuesioner Instruktur

Memberikan Soal-soal Dan Pembahasan Dengan Jelas

Gambar 9 menunjukan bahwa lebih dari setengah siswa menyatakan bahwa instruktur memberikan soal-soal beserta pembahasan dengan jelas. Walau demikian ada yang menyatakan biasa saja bahkan ada yang tidak setuju. Berdasarkan pengamatan selama kegiatan, ada beberapa siswa yang tambak kurang fokus mungkin dikarenakan waktu kegiatan yang sudah siang, sehingga saat pembahasan soal kurang jelas menrut beberapa siswa. Namun hal ini menjadi masukan pagi kami untuk lebih memperhatikan keadaan dan lebih jelas lagi dalam membahas soal-soal pada kegiatan nantinya dan mencoba menggunakan soalsoal yang berstandar tingkat tinggi. Menurut (Ahmad et al., 2018) jika soal yang diberikan standarnya adalah keterampilan berpikir tingkat tinggi artinya keterampilan berpikir pada tingkat yang tidak hanya menghafal.

c. Instruktur membantu siswa memahami materi dan soal dengan baik

Hasil angket kuesioner yang diberikan kepada siswa dengan pernyataan bahwa "Instruktur membantu siswa memahami materi dan soal dengan baik" diketahui $55 \%$ siswa menyatakan sangat setuju, gambar berikut:

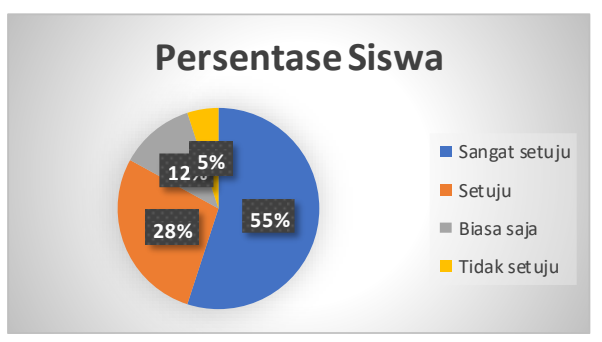

Gambar 10. Hasil Kuesioner Instruktur Membantu Siswa Memahami Materi Dan Soal Dengan Baik

Gambar 10 menunjukan bahwa sebagian besar siswa menyatakan bahwa kegiatan yang diberikan membantu siswa memahami materi dan soal dengan baik. Hal ini tentu memberikan bukti positif bahwa kegiatan seperti ini perlu terus dilanjutkan guna membantu siswa dalam memahami materi dalam menghadapi ujian.

d. Siswa merasa lebih percaya diri menghadapi ujian

Hasil angket kuesioner yang diberikan kepada siswa dengan pernyataan bahwa "Siswa merasa lebih percaya diri menghadapi ujian" diketahui bahwa $38 \%$ siswa menyatakan sangat setuju, perhatikan gambar berikut:

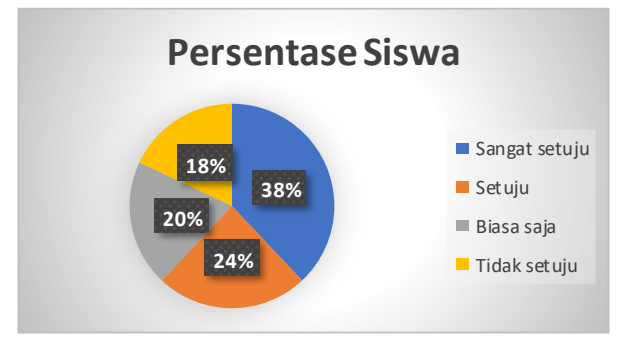

Gambar 11. Hasil Kuesioner Siswa Merasa Lebih Percaya Diri Menghadapi Ujian

Gambar 11 menunjukan hampir setengah siswa kurang setuju bahwa kegiatan yang 

Assurance-Relevance-Interest-Assessment-Satisfaction Di Yayasan Nurul Falah Talok Tangerang Jaka Wijaya Kusuma, Rani Septiani Sukandar, Hamidah

DOI: https://doi.org/10.31004/abdidas.v1i4.43

diberikan membuat siswa lebih percaya diri menghadapi ujian. Hal ini sangat mungkin terjadi karena kegiatan yang diberikan hanya satu kali. Sehingga untuk selanjutnya kegiatan sepereti ini perlu dilakukan beberapa kali sebelum siswa menghadapi ujian, untuk memupuk rasa percaya diri siswa agar lebih yakin dalam menghadapi ujian.

e. Isi materi jelas dan mudah dipahami

Hasil angket kuesioner yang diberikan kepada siswa dengan pernyataan bahwa "Isi materi jelas dan mudah dipahami" diketahui bahwa $52 \%$ siswa menyatakan sangat setuju, perhatikan gambar berikut:

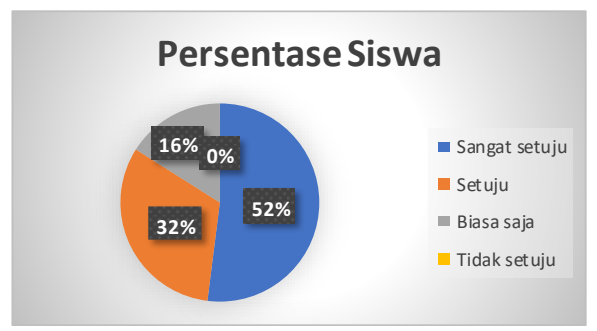

Gambar 12. Hasil Kuesioner Isi Materi Jelas Dan Mudah Dipahami

Gambar 12 menunjukan bahwa tidak ada yang tidak setuju bahwa isi materi jelas dan mudah dipahami. Hal ini menunjukan bahwa kegiatan sudah mencapai tujuan yang diharapkan. Sebelum kegiatan, semua instruktur mempersiapkan materi dan soal beserta pembahasan sedemikian sehingga mudah dipahami oleh siswa. Selama kegiatan pun banyak sekali siswa yang memberikan respon positif dan mampu menjawab pertanyaan singkat seputar materi saat diskusi. f. Proses pembelajaran sangat menyenangkan Hasil angket kuesioner yang diberikan kepada siswa dengan pernyataan bahwa "Proses pembelajaran sangat menyenangkan" diketahui bahwa $73 \%$ siswa menyatakan sangat setuju, perhatikan gambar berikut:

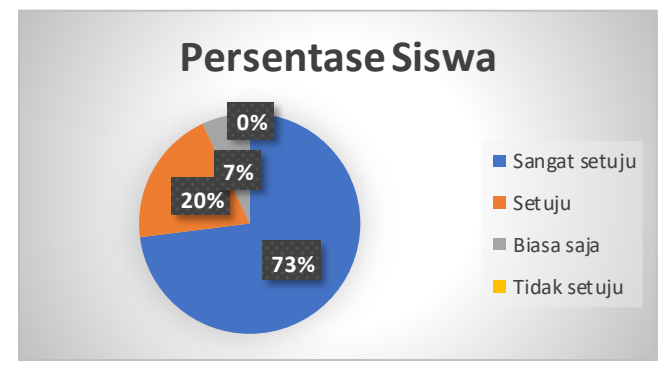

Gambar 13. Hasil Kuesioner Proses Pembelajaran Sangat Menyenangkan

Gambar 13 menunjukan tidak ada satupun siswa yang tidak setuju bahwa kegiatan pembelajaran yang diberikan sangat menyenangkan. Seperti yang dikatakan (Anisah \& Fajriah, 2019) bahwa model pembelajaran ARIAS merupakan kegiatan pembelajaran yang dikemas dengan menjaga psikologi siswa dalam memotivasi atau menarik perhatian siswa. Kegiatan juga diselingi dengan game yang membuat siswa merasa nyaman dan asik selama kegiatan.

Berdasarkan hasil observasi selama kegiatan dan berdasarkan hasil dokumentasi diketahui tidak ada satu siswapun yang tidak terlibat dalam proses kegiatan selama pembelajaran berlangsung. Tiap kelas sangat riuh dan berebutan dalam menjawab pertanyaan ataupun memberikan pertanyaan seputar materi atau soal yang sedang disampaikan. 

Assurance-Relevance-Interest-Assessment-Satisfaction Di Yayasan Nurul Falah Talok Tangerang Jaka Wijaya Kusuma, Rani Septiani Sukandar, Hamidah

DOI: https://doi.org/10.31004/abdidas.v1i4.43

Terlebih pada sesi membahas soal-soal matematika yang sering muncul selama ujian serta memberikan kiat-kiat siap menghadapi ujian, semua siswa tampak antusian menyimak dan melakukan tanya jawab. Hal ini jelas dikarenakan mereka merasa itu merupakan hal yang sangat membantu guna menghadapi ujian yang dekat lagi akan berlangsung.

Selanjutnya dilakukan wawancara langsung kepada beberapa siswa secara acak, dan siswa menyampaikan bagaimana siswa sangat tertarik dengan proses pembelajaran yang dialaminya. Mereka merasa antusias dan ingin proses pembelajaran seperti ini terus berlangsung selama pembelajaran. Menurut siswa, materi yang disampaikan terasa lebih mudah dipahami karena dikaitkan dengan dunia nyata dan mereka merasa memerlukan materi yang sedang disampaikan tersebut. Adanya game merupakan salah satu sesi yang menurut mereka bagian yang menghidupkan suasana pembelajaran dan menarik perhatian. Selanjutnya sesi reward merupakan bagian yang memotivasi siswa untuk terus terlibat selama proses pembelajaran karena merasa dihargai. Yang lebih penting menurut siswa adalah saat sesi kiatkiat siap menghadapi ujian, sesi ini dianggap siswa memotivasinya untuk lebih percaya pada kemampuan diri sendiri dan mengubah pandangannya terhadap soal matematika menjadi sedikit lebih mudah.

\section{SIMPULAN}

Terlaksananya seluruh kegiatan pada program pengabdian kepada masyarakat bekerjasama dengan Yayasan Nurul Falah Talok
Tangerang menunjukan bahwa proses pembelajaran dengan model ARIAS berjalan dengan baik dan terbukti meningkatkan rasa percaya diri siswa dalam menghadapi ujian sekaligus meningkatkan kemampuan matematika siswa dengan cara menciptakan suasana kelas yang aktif dan menyenangkan.

Hal ini terlihat dari hasil kuesioner yang menyatakan bahwa $68 \%$ siswa sangat setuju bahwa instruktur memberi kesempatan kepada siswa untuk bertanya, 52\% \% siswa sangat setuju bahwa instruktur memberikan soal-soal dan pembahasan dengan jelas, 55\% siswa sangat setuju bahwa instruktur membantu siswa memahami materi dan soal dengan baik, 38\% siswa sangat setuju bahwa siswa merasa lebih percaya diri menghadapi ujian, $52 \%$ siswa sangat setuju bahwa isi materi jelas dan mudah dipahami, dan $73 \%$ siswa sangat setuju bahwa proses pembelajaran sangat menyenangkan.

\section{UCAPAN TERIMA KASIH}

Tim penulis mengucapkan terima kasih kepada Lembaga Penelitian dan Pengabdian kepapada Masyarakat (LP2M) Universitas Bina Bangsa Banten yang telah memfasilitasi kegiatan pengabdian ini sehingga terlaksana dengan baik. Tim penulis juga mengucapkan terima kasih kepada Ketua Yayasan, kepala sekolah, dan guruguru, di Nurul Falah Talok Tangerang yang telah menyambut baik dan memfasilitasi kegiatan pengabdian ini sehingga terlaksana dengan baik. Tak lupa pula kami ucapkan terima kasih kepada para siswa MA dan MT's di Nurul Falah Talok Tangerang yang telah menyambut baik dan 

Assurance-Relevance-Interest-Assessment-Satisfaction Di Yayasan Nurul Falah Talok Tangerang Jaka Wijaya Kusuma, Rani Septiani Sukandar, Hamidah

DOI: https://doi.org/10.31004/abdidas.v1i4.43

berpartisipasi dengan aktif selama proses kegiatan berlangsung.

\section{DAFTAR PUSTAKA}

Ahmad, S., Kenedi, A. K., \& Masniladevi, M. (2018). Instrumen Hots Matematika Bagi Mahasiswa Pgsd. JURNAL PAJAR (Pendidikan Dan Pengajaran), 2(6), 905. https://doi.org/10.33578/pjr.v2i6.6530

Anisah, H., \& Fajriah, N. (2019). Meningkatkan Minat Belajar Siswa SMA Dalam Pembelajaran Matematika Melalui Penerapan Model Pembelajaran ARIAS. SENPIKA II FKIP Universitas Lambung Mangkurat Banjarmasin, 5(11), 114-122.

Hamidah, \& Kusuma, J. W. (2019). Kolaborasi Model Assurance-Relevance-InterestAssessment-Satisfaction Dengan ThinkTalk-Write Untuk Meningkatkan Motivasi Berprestasi Dan Kemampuan Berpikir Kritis Siswa. GAUSS: Jurnal Pendidikan Matematika, 02(02), 24-37.

MASLICHAH KUMALANINGRUM, D. (2013). Pemberian Penguatan (Reinforcement) Dalam Pembelajaran Matematika Pada Materi Sistem Persamaan Linear Dua Variabel (Spldv) Di Kelas Viii Smp AlAzhar Menganti Gresik. MATHEdunesa, 2(1).

Mohammad Imam Utoyo, Siti Erum Megawati, S.

Z. (2019). PENINGKATAN KEMAMPUAN MATEMATIKA PESERTA DIDIK SMP MELALUI PEMBENTUKAN KLINIK MATEMATIKA DI SMPN 7 SURABAYA MATHEMATICAL. 3(2), 75-79.

Nur, N. D., \& Dkk. (2013). Implementasi Pemberian Penguatan Dalam Pembelajaran Kooperatif Tipe Numbered Head Together (Nht) Untuk Meningkatkan Aktivitas Dan Hasil Belajar Siswa Pada Sub Pokok Bahasan Operasi Hitungbentuk Aljabar Di Kelas Viib Smp Negeri 4 Jember Tahun Ajaran 2012/2. Pancaran, 2(1), 209-216.

Rohman, M. G., \& Susilo, P. H. (2019). Peran Guru Dalam Penggunaan Media
Pembelajaran Berbasis Teknologi Informasi Dan Komunikasi (Tik) Studi Kasus Di Tk Muslimat $\mathrm{Nu}$ Maslakul Huda. Jurnal Reforma, 8(1), 173-177. https://doi.org/10.30736/rfma.v8i1.140 